\title{
Aligning Physical Therapy practice with Brazil's leading Health priorities: a "call to action" in the $21^{\text {st }}$ century
}

\author{
Direcionando a prática da Fisioterapia com as principais prioridades de \\ Saúde no Brasil: uma "chamada para ação" no século XXI
}

Dornelas de Andrade A', Dean $E^{2}$

\begin{abstract}
Introduction: This article serves as a "call to action" for physical therapists in the $21^{\text {st }}$ century with special attention to the needs of Brazilians. Compared with evidence-based practice supporting the use of specific interventions, practice that is informed by contemporary societal and Health priorities has seriously lagged behind over recent decades. "The First Physical Therapy Summit on Global Health" held at the 2007 World Congress of the World Confederation of Physical Therapy (WCPT) in Canada highlighted the discrepancy between current practice trends globally and contemporary definitions of Physical Therapy (that subsume words such as health, well-being, quality of life, health promotion and prevention); the leading Health priorities within the WCPT regions; the proportions of physical therapists practicing in these priority areas; and the proportions of entry-level Physical Therapy professional education devoted to them. In the $20^{\text {th }}$ century, the profession strived to align itself with societal needs, for example the world wars and poliomyelitis epidemics. Over the past 50 years, lifestyle conditions including ischemic heart disease, smoking-related conditions, hypertension, stroke, obesity, diabetes and cancer have predominated. Despite a remarkable shift from communicable diseases to non-communicable conditions over the past century, the profile of lifestyle conditions within professional practice and education remains low and disproportional to need. This is particularly striking given the unequivocal data in the literature that supports the costbenefit relationship of noninvasive interventions (primarily Health education and exercise) over the short and long-term, with regard to their prevention, "cure" and management. Often the outcomes from these simple inexpensive interventions for lifestyle conditions are superior to drugs and surgery, which are largely used to mitigate signs and symptoms rather than to address underlying causes. To enable physical therapists to address lifestyle conditions in all individuals and relieve the substantial societal and economic burdens of these conditions, we make several evidence-based recommendations for reducing their morbidity and mortality that can readily be integrated into daily practice. By systematically incorporating these into practice, physical therapists can make it possible for physicians and surgeons to use their time and expertise more effectively. Conclusions: We propose that the Brazilian Physical Therapy community should be strategically positioned to become a model and leader in addressing global Health priorities.
\end{abstract}

Key words: evidence-based practice; hypertension; ischemic heart disease; lifestyle conditions; obesity; type 2 diabetes.

\section{Resumo}

Introdução: O presente artigo é uma "chamada para ação" aos fisioterapeutas no século XXI, com especial atenção às necessidades dos brasileiros. Em comparação com a prática baseada em evidências, com o apoio do uso de determinadas intervenções, a prática em uso pela sociedade contemporânea considerando as prioridades de Saúde se mostra atrasada nas últimas décadas. "O Primeiro Encontro de Fisioterapia em Saúde Global”, realizado no Congresso Mundial da Confederação Mundial de Fisioterapia (WCPT), em 2007, no Canadá, enfatizou a discrepância entre as tendências globais da prática atual e as definições contemporâneas da fisioterapia (que agrupa palavras como saúde, bem estar, qualidade de vida, promoção de saúde e prevenção); as principais prioridades de Saúde nas regiões do WCPT; a proporção de fisioterapeutas trabalhando nestas áreas de prioridade e a proporção de cursos de graduação profissional dedicados a tais áreas. No século XX, a profissão visava alinhamento com as necessidades sociais, como por exemplo, as guerras mundiais e a epidemia de poliomielite. Nos últimos 50 anos, predominaram as condições relacionadas ao estilo de vida, incluindo doença cardíaca isquêmica, doenças relacionadas ao fumo, hipertensão, acidente vascular cerebral, obesidade, diabetes

Department of Physical Therapy, Universidade Federal de Pernambuco (UFPE) - Recife (PE), Brazil

${ }^{2}$ Department of Physical Therapy, Faculty of Medicine, University of British Columbia, Vancouver (BC), Canada.

Correspondence to: Armele Dornelas de Andrade, Departamento de Fisioterapia, Universidade Federal de Pernambuco, Avenida Arthur de Sá, s/n, Cidade Universitária, Recife (PE), Brazil, e-mail: armele@pq.cnpq.br 
e câncer. Apesar da marcante mudança de padrão de doenças contagiosas para doenças não contagiosas no último século, a inclusão do perfil das condições de estilo de vida na prática profissional permanece baixo e desproporcional à real necessidade. Isto é particularmente notável quando os dados inequívocos da literatura são considerados, apoiando a relação custo-benefício das intervenções não invasivas (principalmente educação em Saúde e exercícios) tanto em curto quanto em longo-prazo, considerando a prevenção, "cura" e cuidados. Freqüentemente, os desfechos destas intervenções simples e baratas no estilo de vida são superiores aos medicamentos e às cirurgias, que são amplamente utilizados para mitigar sinais e sintomas e que não atingem diretamente as causas de tais condições. Para capacitar os fisioterapeutas na abordagem do estilo de vida e para diminuir o grande fardo social e econômico destas condições, fazemos aqui diversas recomendações baseadas em evidências que podem ser imediatamente incluídas na prática diária, visando a redução da morbidade e mortalidade. Através da incorporação sistemática destas medidas na prática, os fisioterapeutas podem tornar possível o uso mais eficiente do tempo e do conhecimento dos médicos e cirurgiões. Conclusões: Propõem-se que a comunidade brasileira de fisioterapia deva ter uma posição estratégica com a finalidade de se tornar modelo e líder das prioridades globais de Saúde.

Palavras-chave: prática baseada em evidências; hipertensão; doença cardíaca isquêmica; condições do estilo de vida; obesidade; diabetes tipo 2.

\section{Introduction $: \because$.}

This article is a "call to action" for physical therapists to shift their paradigm of practice in the $21^{\text {st }}$ century so that they can better address the urgent health care priorities of today. Despite the importance of evidence-based practice to support the effectiveness of specific interventions, overall practice needs to be informed by contemporary societal and Health priorities. Contemporary physical therapists need to practice within the context of societal need and, on this basis, establish their care priorities for their practices and for given clients or patients. Within this context, they then need to prescribe the most evidence-based interventions to address the care priorities. In addition, such evidence-informed practice, id est, practice based on societal priorities, needs to inform professional entrylevel education curricula.

Determinants or informants of practice priorities have received relatively little attention in recent decades. The present paper addresses this issue and how it can be remedied in daily practice. Firstly, the data that served as the basis for the "First Physical Therapy Summit on Global Health"1 at the 2007 Congress of the World Confederation of Physical Therapy (WCPT) in Canada are described, along with how these data need to inform contemporary healthcare service priorities, including Physical Therapy practice. Lifestyle conditions including ischemic heart disease, smoking-related conditions, hypertension, stroke, obesity, diabetes and cancer are pandemic in Brazil as well as globally and are projected to remain so throughout the $21^{\text {st }}$ century. Next, the literature relating to the evidence base for exploiting noninvasive interventions associated with Physical Therapy, namely education and exercise, is described. The evidence gives unequivocal support to the notion that simple cost-effective interventions really are effective in preventing and in some cases "curing" or managing these deadly conditions. How physical therapists can readily assess and evaluate risk factors for lifestyle conditions in all patients (children and adults alike) and how risk factor modification through lifestyle changes can be implemented clinically is outlined. Finally, we propose that the Brazilian Physical Therapy community has unique qualities that can establish the profession as a model and leader for Physical Therapy globally.

\section{"The First Physical Therapy Summit on Global Health"}

This seminal Physical Therapy summit highlighted the evidence showing the discrepancy between current practice trends and contemporary definitions of Physical Therapy (which subsume words such as health, well-being, quality of life, health promotion and prevention); the leading Health priorities within the five WCPT regions; the proportion of physical therapists practicing in these priority areas; and the proportion of entry-level Physical Therapy professional education devoted to them ${ }^{1}$. In the $20^{\text {th }}$ century, Physical Therapy aligned itself with societal need in response to the world wars and poliomyelitis epidemics. During these epidemics, care for patients requiring respiratory support and mechanical ventilation became integrated into Physical Therapy practice. Over the latter part of the $20^{\text {th }}$ century and the beginning of the $21^{\text {st }}$ century, lifestyle conditions including ischemic heart disease, smoking-related conditions, hypertension, stroke, obesity, diabetes and cancer have predominated. Despite this remarkable trend, the profile of lifestyle conditions within Physical Therapy practice and education remains relatively low. This is particularly striking given the unequivocal data in the literature that gives support to the notion that noninvasive interventions (primarily Health education and exercise) present an effective cost-benefit relationship over the short and long-term with regard to prevention, cure and management ${ }^{2,3}$.

These issues and the implications of the findings from the Summit have recently been addressed in a special issue on 
Physical Therapy practice in the $21^{\text {st }}$ century. ${ }^{4}$ This seminal issue includes state-of-the-art articles on evidence-informed Physical Therapy during this century and how contemporary practice can readily be aligned with epidemiological indicators. Specifically, the topics include the effectiveness of brief advice in changing health-related behavior in clinical practice with special reference to stopping smoking; nutritional assessments for all clients and patients including empirical support for body mass index, waist circumference and hip-to-waist ratio, and support for physical therapists providing basic nutritional recommendations or referring patients to dieticians as indicated; building sustainability into health-related behavioral change programs with special reference to exercise recommendations over the long-term; stress assessment and reduction; and sleep assessment and basic recommendations for improvement of sleep quality. The recommendations overall encourage physical therapists to evaluate their clients and patients' health, in addition to their illnesses and dysfunctions, which have until now been physical therapists' principal focus. This dual focus is also consistent with the World Health Organization's (WHO) International Classification of Health, Disability and Functioning, which has been adopted by the WCPT and by an increasing number of its member countries (a Brazilian version was published in $2003^{6}$ ). In this way, risk factors can readily be identified, interventions can be prescribed and outcomes from risk factor reduction can be followed systematically. Integrated holistic care of this nature, within the profession and across the professions within the healthcare team, is highly consistent with healthcare service delivery this century. The traditional biomedical focus on single impairments does little to address lifestyle risk factors and their manifestations. Risk factors and their reduction are the concern of every physical therapist, and not only those in the cardiovascular and respiratory specialties. Many patients with musculoskeletal or neuromuscular conditions have one or more health risk factors, such that while the musculoskeletal complaint presented needs to be addressed, this often pales in comparison with the impact of the risk factors, for example high blood pressure, obesity and type 2 diabetes.

\section{Lifestyle conditions are Brazil's primary Health priorities}

The major social and economic burdens of disease in Brazil are attributed to lifestyle conditions ${ }^{7}$. Table 1 shows the leading causes of death in Brazil and Table 2 shows the leading causes of death for South American countries overall. While the sequence of conditions may vary somewhat between countries, the healthcare priorities are similar. These profiles increasingly resemble the profiles of high-income countries and it is likely that they reflect Western lifestyle practices, which are becoming prevalent through economic development. Despite medical and surgical interventions, lifestyle conditions are generally increasing in prevalence because the underlying causes are not being addressed. Although the WHO proclaims that these conditions are "largely" preventable, they are projected to contribute predominantly to healthcare challenges and suffering worldwide throughout this century. For these reasons, these conditions need to be a primary concern for physical therapists who specialize in noninvasive approaches and have the evidence-based capacity to prevent, and sometimes "cure" or manage these conditions. Signs of these preventable lethal conditions are now appearing in children, and thus they can no longer be classified as adult conditions.

\section{Effectiveness of noninvasive approaches to lifestyle conditions}

Most Brazilians today, including children, have one or more risk factors for one or more lifestyle conditions. Economic growth and greater wealth are contributing towards higher fat and sugar in the diet, less fiber consumption and reduced physical activity ${ }^{8}$. There is substantial evidence to support exploitation of noninvasive Physical Therapy interventions, including health education and physical activity and exercise. These are the interventions of choice for people with risk factors for lifestyle conditions or their manifestations. Given that smoking is the leading cause of preventable morbidity and mortality', the primary Physical Therapy concern needs to be prevention of smoking among all clients or patients who are smokers ${ }^{10}$. Systematic brief advice in addition to referring some individuals to counselors or facilities for stopping smoking may be effective. However, regardless of this, quitting smoking is challenging and requires a team approach, including a physician participating and supporting the smoker.

Other health-related behavioral changes that need to be instituted by contemporary physical therapists include nutritional recommendations, weight reduction, increased physical activity and exercise, stress management and improved sleep. Just as in other clinical specialties, the needs for health education need to be objectively assessed by using valid and reliable outcome measurements. The individual's learning style and expectations ${ }^{11}$ also need to be evaluated so that the health education can be appropriately tailored for optimal long-term success of the intervention. Inherent to this process is systematic follow-up.

The work of Ornish et al has established unequivocally that atherosclerosis reverses with lifestyle change ${ }^{12,13}$. Similarly, hypertension ${ }^{14,15}$ and diabetes ${ }^{16,17}$ can be reversed or minimized in many individuals, by means of optimized nutrition, and this 
effect is augmented with the addition of regular physical activity. Type 2 diabetes can be prevented and reversed in many clients or patients through diet alone, and this effect can be enhanced with the addition of regular physical activity and weight control.

Optimal body composition and weight is essential for lifelong health, function, and wellbeing over the life cycle, and for reducing the risk of premature death and prolonged end-of-life morbidity ${ }^{18-21}$. High body mass index is a risk factor for all causes of mortality and multisystemic morbidity ${ }^{22,23}$. In addition to the association of obesity with mortality, it has been linked with cancers, cardiovascular diseases, hypertension, type 2 diabetes, respiratory conditions, musculoskeletal disorders, work disability, depression and other mental dysfunction. Furthermore, the impact of obesity is accentuated in older people.

Regular physical activity and exercise are necessary for human growth and development, and for optimal health and well-being ${ }^{3}$. Reduced physical activity has been implicated as a risk factor for ischemic heart disease, hypertension, stroke, obesity, diabetes and some cancers. In addition, reduced physical activity has been implicated in the etiology of osteoporosis. Although of concern in adults, inactivity in children reduces the opportunity for optimal bone deposition during the growing years, thus placing them more at risk of osteoporosis in their adult years.

Stress is a well-established health risk factor. Recent work has focused on daily hassles and irritants ${ }^{24}$, whereas earlier investigators predicted future health risk based on the type and degree of major life stressors ${ }^{25}$. This work has been supplemented with studies on individual responses to stress. Studies on men who tended to experience hostility and aggression found that they faired less well than men who did not experience these situations ${ }^{26}$. Such stress compounds the effects of lifestyle conditions and accumulates, such that it is eventually manifested through conditions such as ischemic heart disease and hypertension. Minor stresses or hassles that occur in daily life may also accumulate and have an impact on health. Stress can impact an individual's quality and quantity of sleep. In turn, chronically disturbed sleep can have systemic clinical manifestations and impair functional capacity ${ }^{27}$, as well as being impaired secondary to other pathological conditions.

Violence and wars are all too common throughout the world and seriously compromise psychosocial wellbeing, as well as inflicting physical injury and potentially permanent functional loss. In addition, violence perpetrated against an individual inevitably impacts that individual's family and the community. In many South American countries (Table 2) including Brazil (Table 1), violent death is among the top ten leading causes of mortality. With regard to social determinants of health, individuals' health reflects the health of the communities in which they live.
Table 1. The leading causes of mortality in Brazil.

\begin{tabular}{ll}
\hline Rank & Causes of death \\
\hline $1^{0}$ & Ischemic heart disease \\
\hline $2^{0}$ & Cerebrovascular disease \\
\hline $3^{0}$ & Perinatal conditions \\
\hline $4^{0}$ & 4. Violence \\
\hline $5^{0}$ & 5. Diabetes mellitus \\
\hline $6^{0}$ & 6. Lower respiratory infections \\
\hline $7^{0}$ & 7. Chronic obstructive pulmonary disease \\
\hline $8^{0}$ & 8. Hypertensive heart disease \\
\hline $9^{0}$ & 9. Road traffic accidents \\
\hline $10^{\circ}$ & 10. Inflammatory heart disease \\
\hline
\end{tabular}

Source: Mortality country fact sheets 2006: http://www.who.int/whosis/mort/profiles/en/

Table 2. The leading causes of mortality across countries in South America.

\begin{tabular}{ll}
\hline Rank & Causes of death \\
\hline $1^{0}$ & Ischemic heart disease \\
\hline $2^{0}$ & Cerebrovascular disease \\
\hline $3^{0}$ & Respiratory infections \\
\hline $4^{0}$ & Diabetes mellitus \\
\hline $5^{0}$ & Cancer \\
\hline $6^{0}$ & Perinatal conditions \\
\hline $7^{0}$ & Violence \\
\hline $8^{0}$ & Chronic obstructive pulmonary disease \\
\hline $9^{0}$ & Hypertensive heart disease \\
\hline $10^{\circ}$ & Tuberculosis \\
\hline
\end{tabular}

Source: Mortality country fact sheets 2006: http://www.who.int/whosis/mort/profiles/en/

Therefore, physical therapists who are committed to health need increasingly to think beyond the individual, id est to consider an individual's social context, family, social environment and school and work environments, along with the safety and security of public places. More fundamentally, they need to serve as activists advocating the availability of clean water for every individual on the planet, wholesome uncontaminated food sources and reliable and effective sanitation and waste disposal services. Beyond essential services, physical therapists need to support education for all, with a view to wealth equity. Throughout the world, wealth inequity is increasingly prevalent: poverty and homelessness are becoming prevalent in high-income countries in which the population in the middle-income bracket is shrinking.

The outcomes from noninvasive interventions are often shown to be superior to drugs and surgery, which typically mitigate signs and symptoms, rather than address underlying causes. Through addressing lifestyle conditions in all individuals, along with their substantial societal and economic burdens, physical therapists can make it possible for physicians and surgeons to use their time and expertise more effectively.

\section{Practice implications}

Twenty-first century Physical Therapy practice calls for a complete health assessment and risk factor assessment in 
all clients or patients, whether they are adults or children, in order to provide a profile of their general health and a basis for risk factor reduction interventions and recommendations, and as a basis for risk factor status re-evaluation over time (see review $^{28}$ ). Risk factors can be quantified based on established tools, which can provide standardized outcome measurements as well as assessments of the findings.

Health profiles should include detailed smoking history, including attempts to give up smoking and any successes, nutritional profile, anthropometric profile (waist girth, waistto-hip ratio and body mass index), physical activity and exercise profiles, stress profile and sleep profile. These should be constructed so that they provide a thorough assessment and make it possible to prescribe specific interventions to meet individual needs, and also so that they can serve as outcome evaluation tools over time.

The risk factor assessment tools that are available are reliable and have been validated in developed countries. They include tools published by the Harvard School of Public Health $^{29}$ (HSPH) that assess disease risk relating to cancer, diabetes, stroke and ischemic heart disease. Currently, these tools are completed on-line. The results are scored and categorized based on an individual's risk relative to the population, matched for gender and age. Based on Framingham study data, the global health assessment ${ }^{30}$ consists of only six questions including age, gender, smoking history, diagnosis of diabetes and blood cholesterol levels. Risk charts for men and women illustrate individuals' absolute and relative risks graphically, in color. These risk levels relate to primary prevention. If an individual has had a prior atherosclerotic event, the risk of subsequent is increased.

Because the risk factors for ischemic heart disease are common for other lifestyle conditions or at least present associations with these conditions, modification of the constituent risk factors within these tools could minimize an individual's risk in relation to one or more lifestyle conditions. Atherosclerosis risk can predispose an individual to cerebrovascular disease, sexual dysfunction (erectile dysfunction), hypertension, renal dysfunction and Alzheimer's syndrome. Similarly, metabolic syndrome refers to a cluster of conditions associated with negative lifestyle behavior including insulin resistance and related health problems including obesity, high blood pressure, high cholesterol, high triglycerides, thrombotic state and proinflammatory state $^{31}$. The nutritional regimen that is advocated for people with diabetes is the basis, when coupled with regular physical activity, for a lifestyle that is healthy for people in general, and one byproduct from it is optimal weight control. Finally, longterm studies are needed in Brazil to improve the sensitivity of prediction tools, given that the existing tools have largely been validated in developed countries.
The measurements needed for health risk assessments include body mass index (weight $(\mathrm{kg}) /$ height $\left(\mathrm{m}^{2}\right)$ ), waist circumference and waist-to-hip ratio ${ }^{32}$. Self-reported height and weight tend to be over and underestimated respectively, and therefore these need to be measured in a standardized manner. The normal range of body mass index is 18.5-24.9, overweight is 25-29.9 and obese is 30 and over. The risks to health increase correspondingly as the body mass index goes beyond 25 . Waist measurements among men should be less that $90 \mathrm{~cm}$ and among women, less than $84 \mathrm{~cm}^{33,34}$. The waist-to-hip ratio should be less that 0.9 among men and less than 0.85 among women ${ }^{35}$. Increased waist girth is associated with increased risk of cardiovascular disease, and particularly with increased waist-to-hip ratio. These measurements provide essential health risk assessment data, standardized outcome and evaluation measurements and predictions of health risks. They provide essential feedback to patients in terms of the effectiveness of their efforts towards lifestyle modification.

There is no level of smoking that is consistent with health or frees smokers from its health risks, including heart disease, high blood pressure, stroke, diabetes (a primary link with type 2 diabetes has now been established) and cancer. Links with cancer of most organs have been established, and not just with organs of the respiratory tract. Every smoker needs to be assessed with regard to how much and for how long the individual has smoked, second-hand as well as first-hand smoke exposure, level of physical and psychological nicotine addiction, facilitators for smoking and barriers to quitting, in addition to assessing organ systemic manifestations of smoking.

While the efficacy of behavioral change regarding health has been well established under the strict protocols required for research studies, long-term change has been more challenging for people to achieve. This observation may reflect the absence of sustained motivators for individuals to maintain behavioral changes over time, and inadequate follow-up ${ }^{36}$. In addition, relatively less attention has been paid to this attribute in Health programs for behavioral change, compared with socalled proximal program attributes.

The attributes of contemporary physical therapists that give support to the notion that they are uniquely qualified as health professionals to effect sustained behavioral change for health reasons are now described. An individual's readiness to change behavior in relation to health can be categorized according to the five stages described by Prochaska and DiClemente ${ }^{37}$. The stages include pre-contemplative (the patient is not thinking about changing a specific behavioral pattern at this time), contemplative (thinking about changing), preparation (preparing to change), action (participating in the requisite positive behavioral patterns), maintenance (attainment of health goals and maintenance of healthy practices) and relapse (health goals 
achieved but behavior has relapsed). Individuals' recognition of their stage of readiness to change their deleterious behavior relative to health conveys to them that they have a choice. Exercising a choice shifts responsibility for health appropriately to the individual from the healthcare professional and thereby enhances the patient's sense of self-efficacy and power with regard to health and wellbeing.

The contemporary theories and models of behavioral change for health reasons are described by Rhodes and Fiala in relation to physical activity and exercise ${ }^{38}$. Self-efficacy, as a primary determinant for long-term behavioral change in relation to health, has been one of the most promising topics covered in the literature. Instigating behavioral change for health reasons with an emphasis on the promotion of self-efficacy is therefore supported as a clinical skill required by physical therapists in the $21^{\text {st }}$ century. Motivational interviewing strategies have been showing promise in effecting positive behavioral change relating to health among clients and patients ${ }^{39}$.

\section{Brazilian physical therapists can lead the way}

As a profession, Physical Therapy is uniquely positioned to lead the assault on lifestyle conditions and reverse the trend of these pandemic conditions. First, physical therapists constitute the 15 largest established healthcare profession. Second, contemporary definitions of Physical Therapy include "Health", wellness, wellbeing, "quality of life", health promotion and prevention, and these constructs are valued. Third, the literature gives unequivocal support to the notion that noninvasive interventions, id est, education, physical activity and exercise, are effective in preventing, and in some cases "curing" or managing lifestyle conditions. Noninvasive interventions are often shown to be superior to drugs and surgery, in that they address the underlying problem rather than primarily focusing on sign or symptom reduction. Furthermore, if drugs and surgery are indicated, the severity of signs and symptoms and length of hospital stay can often be reduced when noninvasive strategies are exploited. Physical therapists are the quintessential noninvasive practitioners, $i d$ est they primarily exploit non-drug and non-surgical interventions: these are the principal purview and knowledge base of Physical Therapy.

Brazilian physical therapists are particularly well positioned to lead this movement within the global Physical Therapy profession. First, Brazil has the distinction of having a high number of physical therapists compared with other countries, including high-income countries. Strength lies in numbers, which fosters the opportunity for the role of physical therapists to expand. Second, in high-income countries, changing the direction of practice has become particularly challenging given tighter organizational structure within the profession, focus on specializations and concentration on standards of practice. This trend has contributed to domination of the musculoskeletal specialty, followed by the neuromuscular specialty. This is a potential barrier to making the paradigm shift that is indicated with regard to focusing on lifestyle risk factors and related conditions. Because of this, a middle-income country such as Brazil has a greater chance of being receptive to and making the changes necessary to better serve people's needs overall. Third, although Brazil is showing marked economic strides, the influence of the pharmaceutical industry is less strong than in high-income countries, where effective noninvasive options have been systematically less publicized and exploited, in favor of more costly drug and surgical alternatives. Having less may be a strength in the pursuit of exploiting effective low-cost alternatives in healthcare. Fourth, physical therapists in Brazil can practice without referral, which places them in an autonomous position for effective change within the healthcare delivery system. Fifth, the Brazilian Physical Therapy community not only has grown substantially with regard to numbers over the past few decades but also has grown substantially in terms of its level of professional sophistication and autonomy, both scientifically and clinically. Collectively, these trends give remarkable strength to the Brazilian Physical Therapy community with regard to leadership within the country and globally. And, finally, physical therapists are known to be strong communicators. The nature of their practice is that they have long visits from their clients or patients over a prolonged period of time. This uniquely enables them to effect health-related behavioral change given that no other healthcare providers interact to such an extent as physical therapists do. Further, exceptional communication skills are singularly important in shifting the paradigm of practice within the profession, to educate other stakeholders (patients, the ministry of Health, government, and other healthcare professionals) about such changes. Such skills are also needed in order to practice effectively within a spirit of teamwork with others in the healthcare team, given the complexity of patients' clinical presentations today, with regard to lifestyle comorbidity and the need for an integrated care approach, in order to best prevent, cure and manage contemporary health issues over the long-term. 


\section{Referências bibliográficas : :}

1. World Confederation for Physycal Therapy (homeoage on the Internet). London: The First Physical Therapy Summit on Global Health (cited 2008 May) Available from: www.wcpt.org/congress/2007/programme/symposia/ index.php

2. Dean E. Physical therapy in the $21^{\text {st }}$ century (Part I): Toward practice informed by epidemiology and the crisis of lifestyle conditions. Physiotherapy Theory and Practice. In press.

3. Dean E. Physical therapy in the $21^{\text {st }}$ Century (Part II): Evidence-based practice within the context of evidence-informed practice. Physiotherapy Theory and Practice.In press.

4. Dean E. Physical Therapy in the $21^{\text {st }}$ Century: A Paradigm Shift and Implications. Special Issue. Physiotherapy Theory and Practice. In press.

5. World Health Organization. International Classification of Functioning, Disability and Health. (2002). www.sustainable-design.ie/arch/ICIDH2PFDec-2000.pdf. Retrieved May 2008.

6. Organização Mundial da Saúde. Organização Pan-Americana de Saúde. CIF: Classificação Internacional de Funcionalidade, Incapacidade e Saúde. São Paulo: EDUSP, 2003. 325p.

7. World Health Organization (homepage on the Internet). Mortality Country Fact Sheets 2006 (cited 2008 May). Available from: www.who.int/whosis/ mort/profiles/en/

8. Barreto, SM, Pinheiro, ARO, Sichieri, R, Monteiro CA, Batista Filho, M, Schimidt M et al. Análise da estratégia global para alimentação, atividade física e saúde, da Organização Mundial da Saúde. Epidemiol. Serv. Saúde. 2005;14(1):41-68.

9. Mokdad AH, Marks JS, Stroup DF, Gerberding JL. Actual causes of death in the United States, 2000. JAMA. 2004;291(10):1238-45.

10. Bodner M, Dean E. Advice as a smoking cessation Strategy in physical therapy practice: A systematic review of what works, what doesn't and why. Physiotherapy Theory and Practice. In press.

11. Lau-Walker M. Cardiac rehabilitation: the importance of patientexpectation-a practitioner survey. J Clin Nurs. 2004;13(2):177-84.

12. Ornish D. Avoiding revascularization with lifestyle changes: The Multicenter Lifestyle Demonstration Project. Am J Cardiol. 1998;82(10B):72T-76T.

13. Ornish D, Scherwitz LW, Billings JH, Brown SE, Gould KL, Merritt TA et al. Intensive lifestyle changes for reversal of coronary heart disease. JAMA. 1998;280(23):2001-7.

14. Sacks FM, Obarzanek E, Windhauser MM, Svetkey LP, Vollmer WM, McCullough $\mathrm{M}$ et al. Rationale and design of the Dietary Approaches to Stop Hypertension trial (DASH). A multicenter controlled-feeding study of dietary patterns to lower blood pressure. Ann Epidemiol. 1995;5(2):10818.

15. Appel LJ, Moore TJ, Obarzanek E, Vollmer WM, Svetkey LP, Sacks FM et al. A clinical trial of the effects of dietary patterns on blood pressure. DASH Collaborative Research Group. N Engl J Med. 1997;336(16):1117-24.
16. Hu FB, Stampfer MJ, Solomon C, Liu S, Colditz GA, Speizer FE et al. Physical activity and risk for cardiovascular events in diabetic women. Ann Intern Med. 2001;134(2):96-105.

17. Montonen J, Knekt $P$, Järvinen $R$, Aromaa $A$, Reunanen $A$. Whole-grain and fiber intake and the incidence of type 2 diabetes. Am J Clin Nutr. 2003;77(3):622-9.

18. Lobstein T, Baur L, Uauy R; IASO International Obesity TaskForce. Obesity in children and young people: a crisis in public health. Obes Rev. 2004;5(Suppl 1):4-85.

19. Visscher TL, Seidell JC. The public health impact of obesity. Annu Rev Public Health. 2001;22:355-75.

20. Avenell A, Broom J, Brown TJ, Poobalan A, Aucott L, Stearns SC et al. Systematic review of the long-term effects and economic consequences of treatment for obesity and implications for health improvement. Health Technol Assess. 2004;8(21):iii-iv, 1-182.

21. Thompson D, Wolf AM. The medical-care cost burden of obesity. Obes Rev. 2001;2(3):189-97.

22. Manson JE, Stampfer MJ, Hennekens CH, Willett WC. Body weight and Iongevity: a reassessment. JAMA.1987;257(3):353-8.

23. Sjöström LV. Mortality of severely obese subjects. Am J Clin Nutr. 1992;55(2 Suppl):516S-523S.

24. Jacobs N, Rijsdijk F, Derom C, Vlietinck R, Delespaul P, van Os J et al. Genes making one feel blue in the flow of daily life: a momentary assessment study of gene-stress interaction. Psychosom Med. 2006;68(2):201-6.

25. Holmes TH, Rahe RH. The Social Readjustment Rating Scale. J Psychosom Res. 1967 Aug;11(2):213-8.

26. No authors listed. Overcoming the threat of anger. More than Type A behavior, hostility raises health risks. Heart Advis. 2004;7(11):6.

27. Coren S. Sleep health and its assessment and management in physical therapy Practice: The evidence. Physiotherapy Theory and Practice. In press.

28. Dean E. Epidemiology as a basis for contemporary physical therapy practice. In: Frownfelter D, Dean E, editors. Cardiovascular and Pulmonary Physical Therapy: Evidence and Practice. 4th ed. Elsevier: PA, 2006.

29. Harvard School of Public Health (homepage on the Internet) Boston: Your Disease Risk (cited 2008 May). Available from: www.yourdiseaserisk. harvard.edu and www.cdc.gov/search.do?action=search\&queryText=risk+f actors+epidemilogy+studies

30. Grundy SM, Pasternak R, Greenland P, Smith S Jr, Fuster V. Assessment of cardiovascular risk by use of multiple-risk-factor assessment equations: a statement for healthcare professionals from the American Heart Association and the American College of Cardiology. Circulation. 1999;100(13):1481-92.

31. Grundy SM. Cardiovascular and metabolic risk factors: how can we improve outcomes in the high-risk patient? Am J Med. 2007;120(9 Suppl):S3-8. 
32. Al-Sultan FA, Al-Zanki N. Clinical epidemiology of type 2 diabetes mellitus in Kuwait. Kuwait Medical Journal 2005;37(1):98-104.

33. Janssen I, Katzmarzyk PT, Ross R. Waist circumference and not body mass index explains obesity-related health risk. Am J Clin Nutr. 2004;79(3):379-84.

34. Zhu S, Wang Z, Heshka S, Heo M, Faith MS, Heymsfield SB. Waist circumference and obesity-associated risk factors among whites in the third National Health and Nutrition Examination Survey: clinical action thresholds. Am J Clin Nutr. 2002;76(4):743-9.

35. Yusuf S, Hawken S, Ounpuu S, Bautistia L, Franzosi MG, Commerford P et al. Obesity and the risk of myocardial infarction in 27,000 participants from 52 countries: a case-control study. Lancet. 2005;366(9497):1640-9.
36. Greenland P, Grundy S, Pasternak RC, Lenfant C. Problems on the pathway from risk assessment to risk reduction. Circulation. 1998;97(18):1761-2.

37. Prochaska J0, DiClemente CC. "Transtheoretical therapy: Toward a more integrative model of change." Psychotherapy: Theory, Research and Practice 1982;19(3):276-88

38. Rhodes R, Fiala B. Building motivation and sustainability into the prescription and recommendations for physical activity and exercise in physical therapy practice: The Evidence. Physiotherapy Theory and Practice. In press.

39. Rollnick S, Heather N, Bell A. Negotiating behaviour change in medical settings: the development of brief motivational interviewing. J Ment Health 1992;1:25-37. 